University of Wollongong

Research Online

Faculty of Engineering and Information

Faculty of Engineering and Information

Sciences - Papers: Part A

Sciences

$1-1-2013$

Trace elements in the si furnace. part l: behavior of impurities in quartz during reduction

Elena Dal Martello

NTNU, Trondheim, Norway

Gabriella Tranell

NTNU, Trondheim, Norway

Oleg Ostrovski

University of New South Wales

Guangqing Zhang

University of Wollongong, gzhang@uow.edu.au

Ola Raaness

SINTEF, Trondheim, Norway

See next page for additional authors

Follow this and additional works at: https://ro.uow.edu.au/eispapers

Part of the Engineering Commons, and the Science and Technology Studies Commons

Research Online is the open access institutional repository for the University of Wollongong. For further information contact the UOW Library: research-pubs@uow.edu.au 


\title{
Trace elements in the si furnace. part l: behavior of impurities in quartz during reduction
}

\begin{abstract}
Quartz and carbonaceous materials, which are used in the production of silicon as well as electrodes and refractories in the silicon furnace, contain trace elements mostly in the form of oxides. These oxides can be reduced to gaseous compounds and leave the furnace or stay in the reaction products-metal and slag. This article examines the behavior of trace elements in hydrothermal quartz and quartzite in the reaction of $\mathrm{SiO} 2$ with $\mathrm{Si}$ or $\mathrm{SiC}$. Mixtures of $\mathrm{SiO} 2$ (quartz or quartzite), $\mathrm{SiC}$, and $\mathrm{Si}$ in forms of lumps or pellets were heated to $1923 \mathrm{~K}$ and $2123 \mathrm{~K}\left(1650^{\circ} \mathrm{C}\right.$ and $\left.1850^{\circ} \mathrm{C}\right)$ in high purity graphite crucibles under Argon gas flow. The gaseous compounds condensed in the inner lining of the tube attached to the crucible. The phases present in the reacted charge and the collected condensates were studied quantitatively by X-ray diffraction (XRD) and qualitatively by Electron Probe Micro Analyzer (EPMA). Contaminants in the charge materials, reacted charge and condensate were analyzed by Inductively Coupled Plasma-Mass Spectroscopy (ICP-MS). Muscovite in the mineral phase of quartz melted and formed two immiscible liquid phases: an Al-rich melt at the core of the mineral, and a SiO2-rich melt at the mineral boundaries. $\mathrm{B}, \mathrm{Mn}$, and $\mathrm{Pb}$ in quartz were removed during heating in reducing atmosphere at temperature above $1923 \mathrm{~K}\left(1650^{\circ} \mathrm{C}\right)$. $\mathrm{Mn}, \mathrm{Fe}, \mathrm{Al}$ and $\mathrm{B}$ diffused from quartz into silicon. $\mathrm{P}$ concentration was under the detection limit. Quartzite and hydrothermal quartz had different initial impurity levels: quartzite remained more impure after reduction experiment but approached purity of hydrothermal quartz upon silica reduction.
\end{abstract}

\section{Keywords}

behavior, impurities, quartz, during, reduction, elements, trace, si, furnace, part, i

\section{Disciplines}

Engineering | Science and Technology Studies

\section{Publication Details}

Martello, E. Dal., Tranell, G., Ostrovski, O., Zhang, G., Raaness, O., Larsen, R. Burg., Tang, K. \& Koshy, P. (2013). Trace elements in the si furnace. part I: behavior of impurities in quartz during reduction. Metallurgical and Materials Transactions B: Process Metallurgy and Materials Processing Science, 44 (2), 233-243.

\section{Authors}

Elena Dal Martello, Gabriella Tranell, Oleg Ostrovski, Guangqing Zhang, Ola Raaness, Rune Burg Larsen, Kai Tang, and Pramod Koshy 


\title{
Trace Elements in the Si Furnace. Part I: Behavior of Impurities in Quartz During Reduction
}

\author{
ELENA DAL MARTELLO, GABRIELLA TRANELL, OLEG OSTROVSKI, \\ GUANGQING ZHANG, OLA RAANESS, RUNE BERG LARSEN, KAI TANG, \\ and PRAMOD KOSHY
}

\begin{abstract}
Quartz and carbonaceous materials, which are used in the production of silicon as well as electrodes and refractories in the silicon furnace, contain trace elements mostly in the form of oxides. These oxides can be reduced to gaseous compounds and leave the furnace or stay in the reaction products - metal and slag. This article examines the behavior of trace elements in hydrothermal quartz and quartzite in the reaction of $\mathrm{SiO}_{2}$ with $\mathrm{Si}$ or $\mathrm{SiC}$. Mixtures of $\mathrm{SiO}_{2}$ (quartz or quartzite), $\mathrm{SiC}$, and $\mathrm{Si}$ in forms of lumps or pellets were heated to $1923 \mathrm{~K}$ and $2123 \mathrm{~K}$ $\left(1650^{\circ} \mathrm{C}\right.$ and $\left.1850^{\circ} \mathrm{C}\right)$ in high purity graphite crucibles under Argon gas flow. The gaseous compounds condensed in the inner lining of the tube attached to the crucible. The phases present in the reacted charge and the collected condensates were studied quantitatively by X-ray diffraction (XRD) and qualitatively by Electron Probe Micro Analyzer (EPMA). Contaminants in the charge materials, reacted charge and condensate were analyzed by Inductively Coupled Plasma-Mass Spectroscopy (ICP-MS). Muscovite in the mineral phase of quartz melted and formed two immiscible liquid phases: an Al-rich melt at the core of the mineral, and a $\mathrm{SiO}_{2}$-rich melt at the mineral boundaries. $\mathrm{B}, \mathrm{Mn}$, and $\mathrm{Pb}$ in quartz were removed during heating in reducing atmosphere at temperature above $1923 \mathrm{~K}\left(1650^{\circ} \mathrm{C}\right)$. $\mathrm{Mn}, \mathrm{Fe}, \mathrm{Al}$ and $\mathrm{B}$ diffused from quartz into silicon. P concentration was under the detection limit. Quartzite and hydrothermal quartz had different initial impurity levels: quartzite remained more impure after reduction experiment but approached purity of hydrothermal quartz upon silica reduction.
\end{abstract}

DOI: $10.1007 / \mathrm{s} 11663-012-9717-4$

(C) The Minerals, Metals \& Materials Society and ASM International 2013

\section{INTRODUCTION}

IMPURITIES in silicon affect the final efficiency of silicon solar cells. The required purity of solar grade silicon was brought forward by Coletti and co-workers. ${ }^{[1]}$ The carbothermic production of silicon is an important source of contamination: quartz, carbonaceous materials, as well as electrode and refractories carry detrimental impurities which transfer to silicon. Impurities in carbon material are mainly the oxides and sulfides present in the ash. Because carbon is very porous, the impurities are easily exposed to the furnace gases up in the furnace, and the volatile compounds which form can be easily removed when the charge is still at the top. ${ }^{[2-4]}$ The behavior of the impurities in quartz during the carbothermic reduction is still not well understood. The impurities present in the quartz do not have easy access to the reducing atmosphere compared with carbon

ELENA DAL MARTELLO, Ph.D., GABRIELLA TRANELL, and RUNE BERG LARSEN, Professors, are with NTNU, Trondheim, Norway. Contact e-mails: dalmarte@yahoo.it, dalmarte@material. ntnu.no OLEG OSTROVSKI, Professor, and PRAMOD KOSHY, Research Associate, are with UNSW, Sydney, NSW, Australia. GUANGQING ZHANG, Lecturer, is with UOW, Wollongong, NSW, Australia. OLA RAANESS, Senior Adviser, and KAI TANG, Research Scientist, are with SINTEF, Trondheim, Norway.

Manuscript submitted: June 15, 2012.

Article published online January 29, 2013. because the quartz is not porous. The quartz melts at around $1973 \mathrm{~K}\left(1700^{\circ} \mathrm{C}\right)$ and may not be melted in the production furnace until just above the cavity around the cavity, created by the electric arc. Consequently, the oxides of the additional elements embedded in the quartz are believed to be accessible for reduction once the quartz reaches the cavity, ${ }^{[5]}$ and any volatile compound which may form might not leave the furnace because of the interaction with the upper charge layer. If cracks formed by quartz thermal expansion are invaded by reducing gases, then the impurities can be exposed earlier, however, this is a topic yet to be investigated.

$\mathrm{SiO}(\mathrm{g}), \mathrm{CO}(\mathrm{g}), \mathrm{C}(\mathrm{s})$, and $\mathrm{SiC}(\mathrm{s})$ are reducing agents for the impurity oxides present in the charge material. Oxides of $\mathrm{Ni}, \mathrm{Co}, \mathrm{Fe}, \mathrm{Pb}, \mathrm{Cu}, \mathrm{Cr}, \mathrm{Mn}, \mathrm{Zn}, \mathrm{Na}$, and $\mathrm{K}$ are easily reduced to metals, while oxides of $\mathrm{Ca}, \mathrm{Al}, \mathrm{Ti}$, and $\mathrm{Mg}$ are stable at temperatures and conditions of quartz reduction. Impurities can be removed from quartz with a gas phase if the reduced or oxidic species are volatile. The vapor pressure of the reduced species is also influenced by the activities of the species in the raw materials and reaction products and by the reaction temperature.

Lumpy quartz contains impurities in form of (1) mineral inclusions, (2) liquid inclusions, and (3) trace elements in the quartz lattice. In a recent process developed for production of solar grade silicon from pure raw materials, ${ }^{[6]}$ quartz is charged in the furnace in form of pellets of intermixed $\mathrm{SiO}_{2}$ and $\mathrm{SiC}$. Quartz in 
these pellets is usually refined from mineral inclusions, and does not contain fluid inclusions because most of them are opened during the quartz milling process. An example of a refining route for hydrothermal quartz was studied by Dal Martello et al. ${ }^{[7]}$ Figure 1 describes the different paths and interactions of impurities (mineral inclusions, liquid inclusions, and trace elements) while heating lumpy quartz in a reducing atmosphere. The case of pellets is a simplified version of Figure 1.

Mineral inclusions generally occur at the quartz grain boundaries and often have a melting point below that of quartz. How the mineral interacts with the silica matrix during heating is not clear. The elements can diffuse from the mineral into the silica matrix already at lower temperature or melt and diffuse/react with the matrix at higher temperatures. Alternatively, minerals with high melting points may maintain their initial composition until the silica melts with limited diffusion to the silica matrix. The high-temperature properties of mica and quartz were studied by Hammouda and Pechavant. ${ }^{[8]}$ They performed partial melting of an assemblage of synthetic quartz and millimeter-sized single crystal synthetic fluorine mica fluorophlogopite $\left(\mathrm{KMg}_{3}\right.$ $\left.\left(\mathrm{AlSi}_{3} \mathrm{O}_{10}\right) \mathrm{F}_{2}\right)$. The experiments were run under atmospheric pressure conditions. After attaining $1523 \mathrm{~K}$ $\left(1250^{\circ} \mathrm{C}\right), 1-\mu \mathrm{m}$-thick melt formed between the two reactants. Above $1573 \mathrm{~K}\left(1300^{\circ} \mathrm{C}\right)$ and within 2 hours' run duration, two immiscible melt phases formed: a $\mathrm{SiO}_{2}$-rich melt in contact with the quartz, and a $\mathrm{MgO}$ and F-rich melt in contact with the mica. However, muscovite is the common mica mineral found in quartz, and its high-temperature properties are not yet understood.

Liquid inclusions may contain several phases: liquid, solid, and gas. The most common composition comprises water in solution with $\mathrm{Na}^{+}, \mathrm{K}^{+}, \mathrm{F}^{-}, \mathrm{Cl}^{-}, \mathrm{CO}_{2}$, and $\mathrm{CH}_{4}{ }^{\left[{ }^{9]}\right.}$ However, $\mathrm{Ca}, \mathrm{Cr}, \mathrm{Cu}, \mathrm{Mg}, \mathrm{Mn}, \mathrm{Pb}$, and $\mathrm{U}$ are also likely to be concentrated in submicroscopic fluid inclusions. ${ }^{[10]}$ Fluid inclusions are common in hydrothermal quartz and vary in size from 5 to $20 \mu \mathrm{m}$. It is not known as to how the trace elements in the quartz lattice interact with fluid inclusions during the heating of quartz. The gaseous phase might have formed and have been released from quartz during fluid inclusions decrepitation at temperatures below $873 \mathrm{~K}\left(600^{\circ} \mathrm{C}\right) .^{[11]}$

Trace elements are impurities locked in the quartz lattice and accommodated at lattice-specific sites. Interstitial cations, such as $\mathrm{K}^{+}$, are situated into vacancies or structural channels running parallel to the c-axis and present ionic bonds. ${ }^{[10,12]}$ Substitutional impurities, such as $\mathrm{Ti}^{4+}, \mathrm{Al}^{3+}, \mathrm{Fe}^{3+}, \mathrm{B}^{3+}$, and $\mathrm{P}^{5+}$, replace $\mathrm{Si}^{4+}$ site in the $\mathrm{Si}-\mathrm{O}$ tetrahedral and present strong ionic-covalent bond. ${ }^{[12]}$ How efficiently these impurities can diffuse to the quartz surface and be available to the reducing atmosphere is not well understood. The cations can diffuse to the lumps surface, be reduced to gaseous compounds, and leave the quartz or, alternatively, the cations can remain in the quartz because of a combination of slow diffusivity, long diffusion path, (such as inability for the reducing gas to permeate the quartz cracks), or high stability to reduction into gaseous compounds. If the cracks, featured in solid quartz during heating can be invaded by reducing gases, then the diffusion distance decreases considerably, and the impurities are more easily exposed to reducing atmosphere. However, it is not clear if the reducing gases are able to invade these cracks.

The diffusivity of trace elements in solid quartz in a reducing atmosphere at temperatures between $1973 \mathrm{~K}$ and $2273 \mathrm{~K}\left(1600^{\circ} \mathrm{C}\right.$ and $\left.2000^{\circ} \mathrm{C}\right)$ is not well documented. The only available data on the diffusivity of cations in quartz are in atmospheric air and at temperatures that are not representative of the silicon furnace. ${ }^{[13-19]}$ The diffusion of $\mathrm{Ca}, \mathrm{Na}, \mathrm{Li}, \mathrm{K}$, and $\mathrm{Fe}$ is fast in quartz, while diffusion of $\mathrm{Al}$ and $\mathrm{Ti}$ is significantly slower. In general, small cations diffuse more easily, and voids, cracks and low density structures, such as hightemperature quartz polymorphs, enhance the cations' diffusion. ${ }^{[20,21]}$ Geological studies on the diffusion of impurities during hydrothermal alteration of quartz show that $\mathrm{Fe},{ }^{[22,23]} \mathrm{K}^{[22,24,25]}$ and $\mathrm{B}^{[25]}$ are mobile ions in quartz.
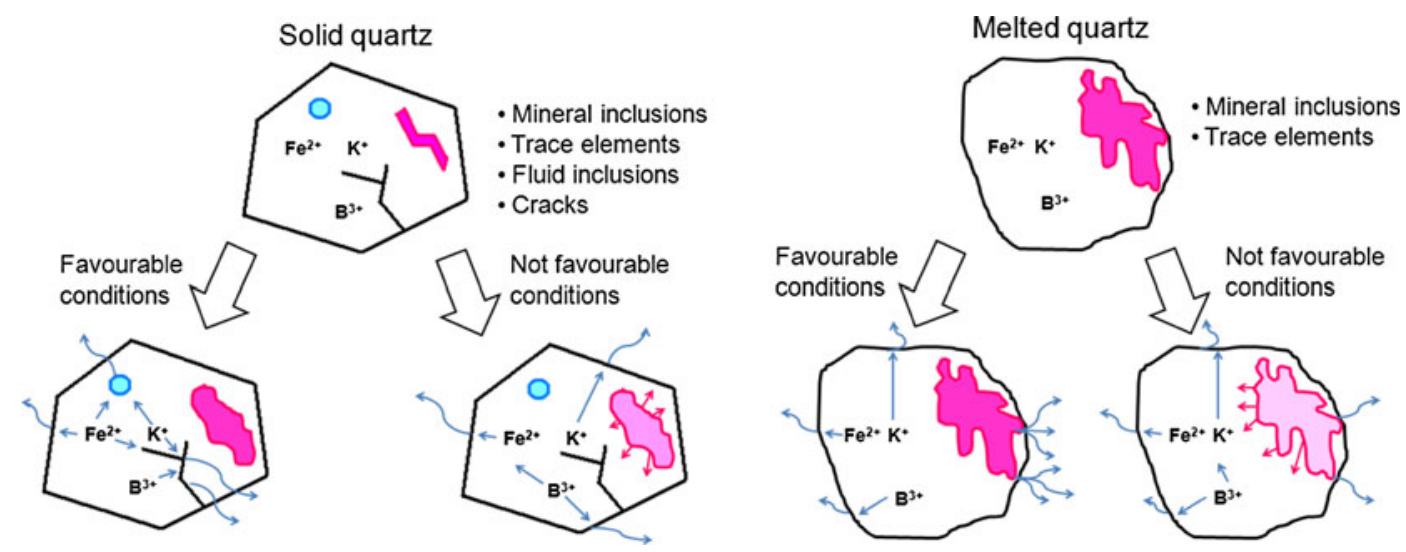

Fig. 1-Possible paths of the impurities in solid and melted lumpy quartz during heating of quartz in reducing atmosphere. The conditions which enhance the formation of gaseous compounds are favorable conditions. These are (1) interaction of trace elements with fluid inclusions and formation of gaseous Cl-based compounds which are liberated during heating of quartz; (2) short diffusion distance of the dissolved impurity to a reductive atmosphere combined with the ability to be reduced to gaseous compounds; and (3) mineral at its initial composition when facing a reducing atmosphere. 
This series of two articles examines the behavior and distribution of the impurities from quartz between reaction solid products and the gas phase. In particular, the purpose of Part 1 is to understand the redistribution of elements in solid and molten quartz and how much and which of the impurities remain in quartz after reduction. The purpose of part 2 is to investigate the concentration and form of impurities in gas and the conditions which enhance gaseous compound's formation.

\section{MATERIALS AND METHODS}

\section{A. Materials}

Hydrothermal vein quartz, quartzite, high-purity $\mathrm{SiC}$, and electronic grade $\mathrm{Si}(\mathrm{Eg}-\mathrm{Si})$ were the materials used in this study. The quartzite was of the common type used for the production of metallurgical silicon and Fe$\mathrm{Si}$ alloys. The hydrothermal quartz is a new high-purity source from a Norwegian deposit; it had been examined in previous studies. ${ }^{[27,28]}$ The electronic grade silicon was supplied by Wacker, and the ultra-pure SiC was produced by reduction of hydrothermal quartz with high-purity carbon black. Ultra-pure saccharine by Danisco AS $\mathrm{C}_{12} \mathrm{H}_{22} \mathrm{O}_{12}$ was used as a binder in the pellet production. Quartz and silicon carbide were investigated both as pellets and lumps. The process of making pellets was described elsewhere. ${ }^{[27]}$

The reactions were studied in ultra pure graphite crucibles of the isotropic type IG-110 supplied by Toyo Tanso and in ultra-pure argon which contained $\mathrm{H}_{2} \mathrm{O}$ $<3.0$ ppmw; $\mathrm{O}_{2}<2.0$ ppmw. Table I summarizes the chemical compositions of $\mathrm{SiC}, \mathrm{Si}$, and graphite provided by suppliers and determined at NTNU. The graphite was analyzed by ICP-AES, SiC by GDMS, and Si by ICP-MS. SiC and $\mathrm{Si}$ were also analyzed by ICP-MS after crushing.

The chemical analyses of the quartz materials determined by ICP-MS at NTNU are presented in Table II. The quartzes charged as pellets were jet milled before pelletizing. Hydrothermal quartz was purer than quartzite and contained generally lower amount of B, Al, Fe, $\mathrm{Mn}$, and $\mathrm{Pb}$. The minerals present in the two quartz sources were identified by EPMA. Fe-rich muscovite and $\mathrm{K}$-feldspar were found in hydrothermal quartz; Ferich muscovite, K-feldspar, clay mineral, calcite, clinochlore, and carbonate were found in quartzite. Al, Fe, and $\mathrm{K}$ were the most abundant elements in the mineral phase among the impurities studied.

\section{B. Experimental Set Up and Conditions}

The reduction experiments were carried out in a 23-kW graphite tube furnace (model 1000-3560-FP20). The furnace chamber was $76 \mathrm{~mm}$ in diameter, and $153 \mathrm{~mm}$ in height. The experimental set-up is schematically presented in Figure 2. A crucible containing the charge materials was connected to a gas ducting tube $500 \mathrm{~mm}$ long and $10 \mathrm{~mm}$ in inner diameter. The tube end outside the furnace was connected to a two-way valve. A type $\mathrm{C}$ thermocouple with hafnium oxide insulator was inserted from the side of the furnace to measure the temperature close to the crucible wall.

Mixtures of $\mathrm{SiO}_{2}: \mathrm{SiC}$ with 1:1 molar ratio, and $\mathrm{SiO}_{2}: \mathrm{Si}$ also with $1: 1$ molar ratio were chosen to represent different zones of the silicon furnace. The mixtures were prepared in the form of lumps and pellets. The experimental matrix is given in Table III. The experimental condition "pellet $\mathrm{SiO}_{2}+\mathrm{SiC}$ " refers to pellets of silica and silicon carbide intermixed. The experimental condition "pellet $\mathrm{SiO}_{2}+\mathrm{Si}$ " refers to pellets of quartz mixed with pieces of silicon. The mixtures were heated at $60^{\circ} \mathrm{C} /$ minutes to $1923 \mathrm{~K}$ or $2123 \mathrm{~K}\left(1650^{\circ} \mathrm{C}\right.$ or $\left.1850^{\circ} \mathrm{C}\right)$. The chosen reaction temperatures $1923 \mathrm{~K}$ and $2123 \mathrm{~K}\left(1650^{\circ} \mathrm{C}\right.$ and $\left.1850^{\circ} \mathrm{C}\right)$ are, respectively, below and above the quartz melting point. The melting point of the hydrothermal quartz was estimated in a reducing atmosphere for a $3-\mathrm{mm}$ particle size to be $2092 \mathrm{~K}\left(1819^{\circ} \mathrm{C}\right) .^{[27]}$ As quartzite contains more contaminants than hydrothermal quartz (Table II) and the impurities in quartz lower the melting point of quartz, ${ }^{[29]}$ quartzite is expected to have a lower melting

Table I. Chemical Analysis (ppmw) of SiC, Si, and Graphite

\begin{tabular}{lcccccccccc}
\hline Trace Element & $\mathrm{B}$ & $\mathrm{P}$ & $\mathrm{K}$ & $\mathrm{Al}$ & $\mathrm{Fe}$ & $\mathrm{Mn}$ & $\mathrm{Zn}$ & $\mathrm{Pb}$ \\
\hline Isotropic graphite type IG-110 (ref. from the supplier) & 0.15 & - & 0.04 & 0.01 & 0.06 & $<0.001$ & - \\
Ultra-pure SiC (ref. from the supplier) & 0.45 & 0.02 & - & 6.1 & 0.37 & - & - \\
Electronic grade silicon (ref. from the supplier) & $<0.001$ & $<0.00$ & - & $<0.001$ & $<0.001$ & $<0.00$ & $<0.001$ & $<0.00$ \\
Ultra-pure SiC after crushing (NTNU) & 1.43 & - & - & 10.9 & 6.8 & 0.44 & 0.07 & 0.01 \\
Ultra-pure SiC after milling (NTNU) & 4.97 & - & - & 267.9 & 39.53 & 1.16 & 2.38 & 0.08 \\
Electronic grade silicon after crushing (NTNU) & 3.3 & - & - & 25.9 & 5.49 & 0.07 & 4.06 & 0.01 \\
\hline
\end{tabular}

Table II. Chemical Analyses (ppmw) of Hydrothermal Quartz and Quartzite After Mechanical Crushing and Jet Milling

\begin{tabular}{|c|c|c|c|c|c|c|c|c|c|c|c|}
\hline Trace element & B & $\mathrm{P}$ & $\mathrm{K}$ & $\mathrm{Al}$ & $\mathrm{Fe}$ & $\mathrm{Mn}$ & $\mathrm{Zn}$ & $\mathrm{Pb}$ & $\mathrm{Cr}$ & $\mathrm{Ni}$ & $\mathrm{Cu}$ \\
\hline Hydrothermal quartz after crushing & 1.4 & $<3$ & $<40$ & 44 & 21 & 0.3 & - & 0.2 & $<1$ & $<1$ & $<1$ \\
\hline Hydrothermal quartz after milling & 3.7 & - & 142 & 199 & 182 & 1.9 & 1.5 & 0.3 & $<1$ & $<1$ & $<1$ \\
\hline Quartzite after crushing & 2.9 & 6.4 & 60 & 453 & 207 & 2.8 & 6.7 & 1.8 & $<1$ & $<1$ & $<1$ \\
\hline Quartzite after milling & 6.4 & 20.3 & 195 & 927 & 571 & 6.3 & 25.3 & 3.9 & $<1$ & $<1$ & $<1$ \\
\hline
\end{tabular}




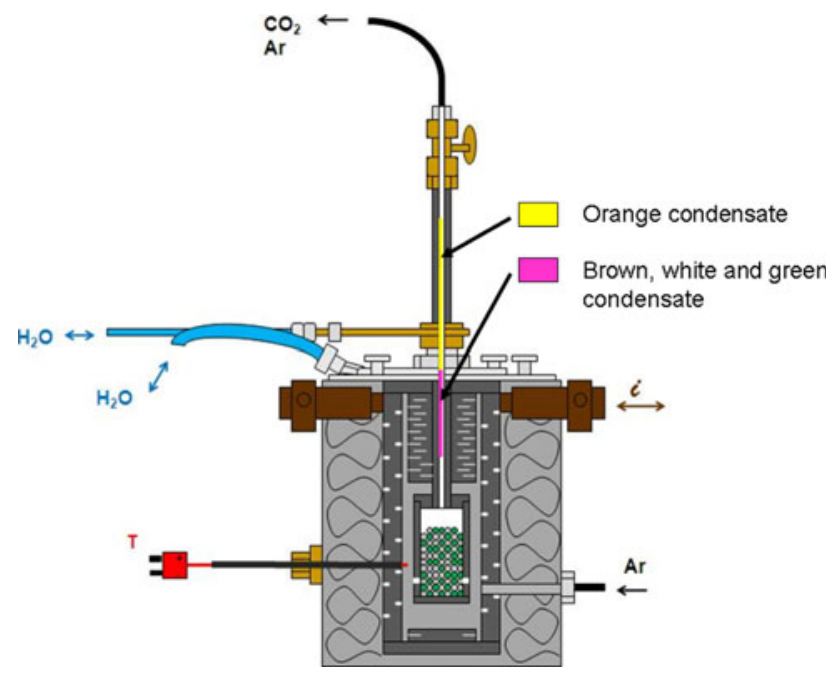

Fig. 2-Experimental set in a graphite tube furnace. The condensate was collected in two regions represented in the picture in pink and yellow. Pink: mixture of white, brown, and green condensate sticking on the tube surface; yellow: orange condensate in flaky-powdery form nonsticking on the tube.

point than hydrothermal quartz. Therefore, a temperature of $1923 \mathrm{~K}\left(1650^{\circ} \mathrm{C}\right)$ was chosen to study the behavior of both quartz-types in their solid states.

Two parallel experiments were run at $1923 \mathrm{~K}$ $\left(1650^{\circ} \mathrm{C}\right)$ using new charge materials in a new crucible in each run and the same ducting tube.

The charge was directly heated to the targeted temperature at $60^{\circ} \mathrm{C} /$ minutes when lumps were used. The charge with pellets was first heated to $1273 \mathrm{~K}\left(1000^{\circ} \mathrm{C}\right)$ and kept for 10 minutes, to ensure the complete volatilization of the binder, and then heated at $60^{\circ} \mathrm{C} /$ minutes to the targeted temperature. The furnace was cleaned before the experiments by heating to $1173 \mathrm{~K}\left(1900^{\circ} \mathrm{C}\right)$ for 3 hours purging argon at $11 /$ minutes $\left(16.6 \mathrm{~cm}^{3} / \mathrm{s}\right)$. Argon passed through a tube furnace containing steel wool at $673 \mathrm{~K}\left(400^{\circ} \mathrm{C}\right)$ before entering the graphite furnace to flush out any oxygen impurity. The furnace was evacuated to $4 \times 10^{-2}$ mbar before purging argon to remove any adsorbed moisture and $\mathrm{CO}_{2}$ from the graphite parts of the furnace. The outer surface of the graphite tube was coated with superglue, to ensure good hermetic condition. The furnace leakage was measured by keeping the furnace at vacuum for 1 day and was estimated to be $1.1 \mathrm{mbar} /$ hour. The temperature along the ducting tube decreased sharply outside the chamber and as a result, a condensate deposited on the inner surface of the tube. The condensate eventually blocked the tube. The experiment was terminated when the overpressure in the chamber, owing to the condensate blockage, reached approximately $50 \mathrm{kPa}$.

\section{Sample Characterization}

Four analytic methods were used for the analysis of the samples after reaction: Inductively Coupled Plasma Mass Spectrometry (ICP-MS); X-Ray Diffraction (XRD); Electron Probe Micro-Analysis (EPMA); and Leco TC 600.
Single phases were taken, where possible, from the reacted charge mix and analyzed by ICP-MS. It was not possible to detach silica from silicon carbide in the mixture "pellets $\mathrm{SiO}_{2}+\mathrm{SiC}$ " after reaction; therefore, the analysis for this experimental series refers to the mixture of $\mathrm{SiC}$ and $\mathrm{SiO}_{2}$.

EPMA, JEOL model $8500 \mathrm{~F}$, was used to identify the trace minerals as inclusions in quartz and to investigate the reacted minerals qualitatively by mapping and quantitatively by point analysis. Standard microanalysis reference materials, Astimex 53 Minerals Mount MINM25-53, were used for the calibration of the instrument. ${ }^{[30]}$

D8 Advance XRD, BRUKER-EVA was used to analyze the reacted quartz.

A Leco TC600 oxygen and nitrogen analyzer was used to determine the oxygen content in the reacted sample. The free carbon content of the charges reacted at $1923 \mathrm{~K}\left(1650^{\circ} \mathrm{C}\right)$ was measured by combustion method. The procedure was based on the Australian Standard for the ash content in coke ${ }^{[31]}$ : powdery sample was heated in air to $1088 \mathrm{~K}\left(815^{\circ} \mathrm{C}\right)$ in a muffle furnace for 180 minutes, and the carbon content was calculated from the mass change after incineration.

\section{ICP-MS Analysis: Problems with SiC Dissolution}

Two procedures of digestion were applied in this study. If a sample contained $\mathrm{SiC}$, then the procedure of digestion was as follows: $20-40$-mg sample was digested in a mixture of $0.5 \mathrm{~mL}$ concentrated $\mathrm{HNO}_{3}+0.5 \mathrm{ml}$ concentrated $\mathrm{H}_{2} \mathrm{SO}_{4}+0.5 \mathrm{~mL}$ concentrated $\mathrm{HF}$ at $518 \mathrm{~K}\left(255^{\circ} \mathrm{C}\right)$ for 1 hour. It should be mentioned that complete digestion of $\mathrm{SiC}$ was not achieved. A sample, which did not contain $\mathrm{SiC}$, was digested in a mixture $0.5 \mathrm{~mL} \mathrm{HF}+1.5 \mathrm{~mL} \mathrm{HNO}_{3}$ at $523 \mathrm{~K}\left(250^{\circ} \mathrm{C}\right)$ for 1 hour. The solution was digested in PTFE containers in a digestion bomb.

The addition of $\mathrm{H}_{2} \mathrm{SO}_{4}$ in the dissolution improved the recovery of the elements. The major effects were on $\mathrm{B}(+15 \mathrm{pct}), \mathrm{P}(+5 \mathrm{pct}), \mathrm{Al}(+10 \mathrm{pct}), \quad$ and $\mathrm{K}$ $(+9$ pct). $\mathrm{Fe}, \mathrm{Mn}$, and $\mathrm{Pb}$ were less affected $(+2 \mathrm{pct})$. Therefore, the results were normalized accordingly.

Standard materials DIABASE W-2, BCS-CRM 313/ 1, NIST 57b ( $\mathrm{Si})$, and JCRM R $021(\mathrm{SiC})$ were used for the ICP-MS calibration. Three scans were run for each sample with an average error of 4 pct.

Tests on standards W-2 and NIST 57b showed that the $\mathrm{B}$ and $\mathrm{P}$ concentrations were very close to the reference values. This means that the losses of $\mathrm{B}$ and $\mathrm{P}$ were negligible during digestion of samples in an autoclave, and the analyses of $\mathrm{B}$ and $\mathrm{P}$ were reliable.

The gaseous products containing mainly $\mathrm{SiO}(\mathrm{g})$ and $\mathrm{CO}(\mathrm{g})$ condense/react to a mixture of $\mathrm{Si}, \mathrm{SiC}$, and $\mathrm{SiO}_{2}$ which will be discussed further in Part 2 of this publication. Gaseous compounds other than $\mathrm{SiO}(\mathrm{g})$ and $\mathrm{CO}(\mathrm{g})$ were suggested to end up in the $\mathrm{SiC}, \mathrm{Si}$, or $\mathrm{SiO}_{2}$. As $\mathrm{SiC}$ was not fully digested, an accurate quantification of those elements is questionable. Silicon carbide is very difficult to digest. The dissolution process is extremely slow because what is really dissolved is not the $\mathrm{SiC}$ itself but a very thin layer (around $100 \mathrm{~nm}$ 
Table III. Experimental Matrix

\begin{tabular}{|c|c|c|c|c|c|c|c|c|}
\hline$\# \operatorname{Exp}$ & Charge mixture & Temperature $\left[\mathrm{K}\left({ }^{\circ} \mathrm{C}\right)\right]$ & Charge type & Quartz Type & $\mathrm{SiO}_{2}$ & $\mathrm{SiC}$ & $\mathrm{Si}$ & $\mathrm{C}$ \\
\hline $\begin{array}{l}2 \\
2\end{array}$ & $\mathrm{SiO}_{2}+\mathrm{SiC}$ & $1923(1650)$ & lumps & $\begin{array}{l}\text { hydro } \\
\text { quartzite }\end{array}$ & $1 \mathrm{~mol}$ & $1 \mathrm{~mol}$ & - & - \\
\hline 2 & & & pellets & $\begin{array}{l}\text { hydro } \\
\text { quartzite }\end{array}$ & $0.9 \mathrm{~mol}$ & $0.9 \mathrm{~mol}$ & - & $0.3 \mathrm{~mol}$ \\
\hline $\begin{array}{l}1 \\
1\end{array}$ & & $1923(1850)$ & lumps & $\begin{array}{l}\text { hydro } \\
\text { quartzite }\end{array}$ & $1 \mathrm{~mol}$ & $1 \mathrm{~mol}$ & - & - \\
\hline $\begin{array}{l}1 \\
1\end{array}$ & & & pellets & $\begin{array}{l}\text { hydro } \\
\text { quartzite }\end{array}$ & $0.9 \mathrm{~mol}$ & $0.9 \mathrm{~mol}$ & - & $0.3 \mathrm{~mol}$ \\
\hline $\begin{array}{l}2 \\
2\end{array}$ & $\mathrm{SiO}_{2}+\mathrm{Si}$ & $1923(1650)$ & lumps & $\begin{array}{l}\text { hydro } \\
\text { quartzite }\end{array}$ & $1 \mathrm{~mol}$ & - & $1 \mathrm{~mol}$ & - \\
\hline $\begin{array}{l}2 \\
2\end{array}$ & & & pellets of $\mathrm{SiO}_{2}$ & $\begin{array}{l}\text { hydro } \\
\text { quartzite }\end{array}$ & $0.9 \mathrm{~mol}$ & - & $1 \mathrm{~mol}$ & $0.5 \mathrm{~mol}$ \\
\hline $\begin{array}{l}1 \\
1\end{array}$ & & $2123(1850)$ & lumps & $\begin{array}{l}\text { hydro } \\
\text { quartzite }\end{array}$ & $1 \mathrm{~mol}$ & - & $1 \mathrm{~mol}$ & - \\
\hline $\begin{array}{l}1 \\
1\end{array}$ & & & pellets of $\mathrm{SiO}_{2}$ & $\begin{array}{l}\text { hydro } \\
\text { quartzite }\end{array}$ & $0.9 \mathrm{~mol}$ & - & $1 \mathrm{~mol}$ & $0.5 \mathrm{~mol}$ \\
\hline
\end{tabular}

$\mathrm{C}$ represents carbon contained in the binder used for manufacturing pellets.

(Presser et al. 2008)) of cristobalite formed on the SiC surface. After the first silica layer had dissolved, a new layer forms by thermal oxidation. As the condensed $\mathrm{SiC}$ is in the form of $\beta: \mathrm{SiC}$ (as will be shown in Part2), which among the $\mathrm{SiC}$ polytypes has a relative open structure, andtherefore, easier to digest, a completely recovery of $\mathrm{SiC}$ in the condensate is assumed.

\section{RESULTS}

\section{A. Morphology of the Reacted Charge}

Table IV summarizes the morphology of the reacted charge for the different experimental conditions. The morphologies of the samples containing hydrothermal quartz were structurally very similar to samples with quartzite. The pictures in Table IV represent samples with hydrothermal quartz. The experimental time, which was limited by tube blockage by the condensate, is also indicated in the table.

Analyses of the oxygen and carbon content in pellets reduced at $1923 \mathrm{~K}\left(1650^{\circ} \mathrm{C}\right)$ showed that silica reacted mainly with carbon in the binder. This series of experiments is not representative for the reaction between silica and silicon carbide but provides some information for the comparison of reactions with quartzite and hydrothermal quartz.

It is worthy to note that at $1923 \mathrm{~K}\left(1650^{\circ} \mathrm{C}\right)$, the charge mix "lumps $\mathrm{SiO}_{2}+\mathrm{SiC}$ " took more time to block the tube with condensate than the charge mix "lumps $\mathrm{SiO}_{2}+\mathrm{Si}$." The situation was the opposite at $2123 \mathrm{~K}\left(1850^{\circ} \mathrm{C}\right)$. This qualitative result agrees with that of Andersen ${ }^{[32]}$ who studied the reactions between $\mathrm{SiO}_{2}+\mathrm{SiC}$ and $\mathrm{SiO}_{2}+\mathrm{Si}$. $\mathrm{He}$ observed that the rate of conversion of the $\mathrm{SiO}_{2}-\mathrm{SiC}$ mixture was two times higher in comparison with the $\mathrm{SiO}_{2}$-Si mixture at $1923 \mathrm{~K}\left(1650^{\circ} \mathrm{C}\right)$ and nine times higher at $2123 \mathrm{~K}\left(1850^{\circ} \mathrm{C}\right)$.

Microstructures of reacted quartz depended on the reaction temperature, charge mix, and initial size.
Reacted lumpy quartz (1-2 in Table IV) at $1923 \mathrm{~K}$ $\left(1650^{\circ} \mathrm{C}\right)$ was still solid and was characterized by a thick network of microns-wide cracks. Cracks in the quartz before and after heating are shown in the micrographs in Figure 3. The distance between cracks was approximately $50 \mu \mathrm{m}$. The reacted quartz was white and visibly porous. Quartzite, originally with a brownish/reddish resemblance, changed to white after reduction. Quartz was crystallized to cristobalite. A few areas of intermediate amorphous phase appeared near the cracks.

Reacted lumpy quartz (3-4 in Table IV) melted at $2123 \mathrm{~K}\left(1850^{\circ} \mathrm{C}\right)$ and cracks disappeared. Melted $\mathrm{SiO}_{2}$ lumps were in the form of numerous spherical aggregates when reacted with $\mathrm{SiC}$, while fused to a single piece when reacted with $\mathrm{Si}$ and cavities, previously filled with silicon, are also visible.

Reacted pellets of quartz (5-6 in Table IV) sintered at $1923 \mathrm{~K}\left(1650^{\circ} \mathrm{C}\right)$ regardless of the charge mix used. Sintering decreases the initial porosity of the charge. Cristobalite in the pelletized charge was the major phase detected by XRD.

Reacted pellets (7-8 in Table IV) melted at $2123 \mathrm{~K}$ $\left(1850^{\circ} \mathrm{C}\right)$. (7) The charge mix " $\mathrm{SiO}_{2}+\mathrm{SiC}$ " at $2123 \mathrm{~K}$ $\left(1850^{\circ} \mathrm{C}\right)$ is characterized by a matrix of amorphous $\mathrm{SiO}_{2}$ containing $\mathrm{SiC}$ pieces. (8) The charge mix " $\mathrm{SiO}_{2}+\mathrm{Si}$ " resembled a quartz sponge stretched structure characterized by openings of 250-500 $\mu \mathrm{m}$ size. This quartz spongy structure was so fluid that it partially ran out of $2-\mathrm{mm}$ holes in the bottom of the graphite crucible which were present to allow the Ar to flow into the crucible. Silicon diffused and reacted into the graphite crucible, reacted with the quartz, and only a small amount was found in the reacted charge.

\section{B. Impurities in Reacted Quartz}

Chemical analysis of the reacted hydrothermal quartz and quartzite was compared with their initial composition. 
Table IV. Reacted Charge Morphology for the Different Experimental Conditions: Visual Observations and Backscattering Analyses

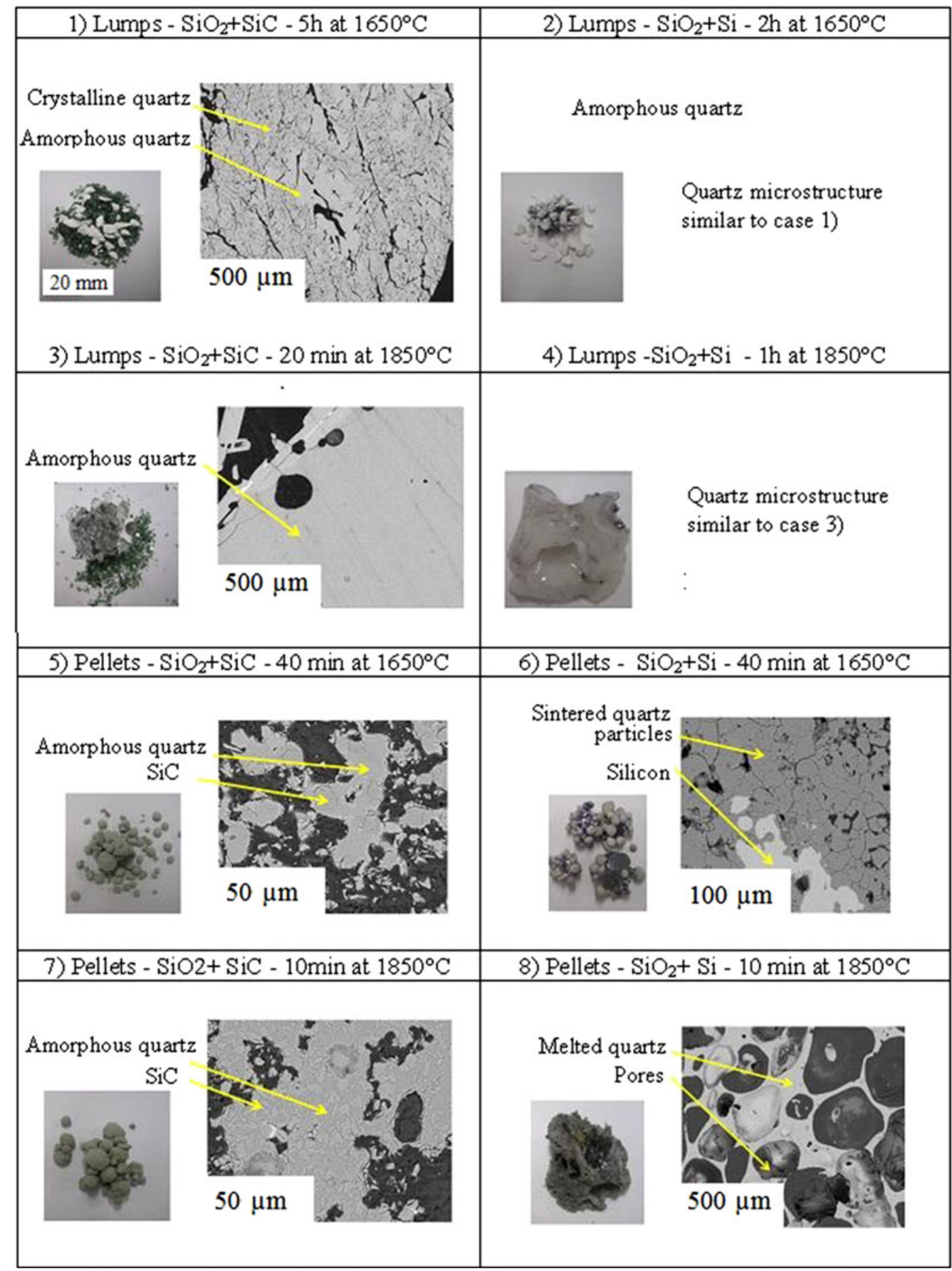

Major focus is on the quartz charge. The cases 1-2 and the cases 3-4 show the same backscattering microstructure of quartz; therefore, only one representative picture for the two cases is shown.

Figure 4 shows the change $\Delta$ in the impurity concentration (ppmw) for the initially charged quartz and the reacted quartz. The parameter $\Delta$ depends on both the reduction of the impurity to the gas phase and the change in the $\mathrm{SiO}_{2}$ mass or $\mathrm{SiO}(\mathrm{g})$ production.
Table V compares concentrations of impurities before and after reaction in hydrothermal quartz and quartzite presented as a ratio (mass). Quartzite was more polluted than hydrothermal quartz both before reduction and after reduction. However, the differences in concentrations 

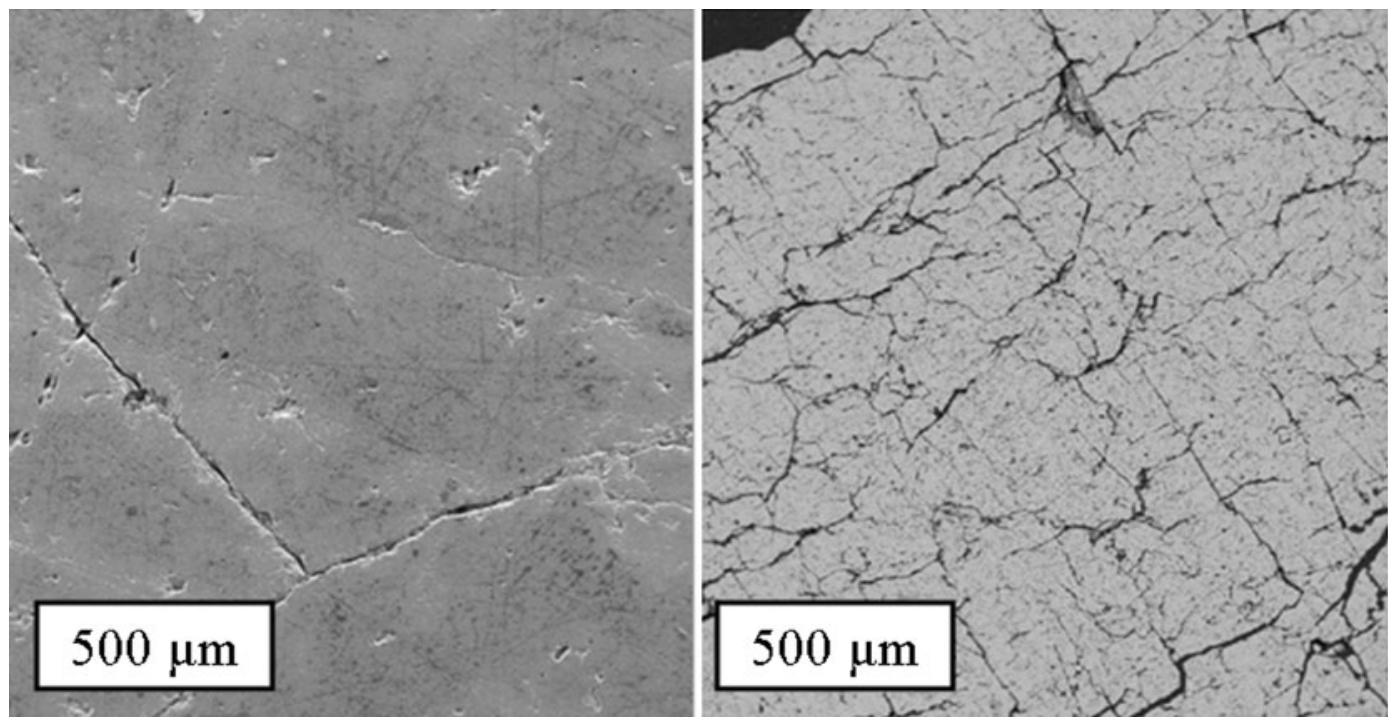

Fig. 3 - On the left: micro cracks, grain boundaries, and porosity in the original quartz sample. On the right: cracks developed in the sample during heating.

decreased after reaction, particularly for the pellet charge $\mathrm{SiO}_{2}+\mathrm{SiC}$ reduced at $1923 \mathrm{~K}\left(1650^{\circ} \mathrm{C}\right)$.

$\mathrm{P}$ values are not reported because the values were under the detection limit (3.4 ppmw). The most consistent trends in change in the concentration were observed for $\mathrm{Pb}, \mathrm{Mn}, \mathrm{B}, \mathrm{Zn}$, and $\mathrm{Al} . \mathrm{Pb}, \mathrm{Mn}, \mathrm{Zn}$, and $\mathrm{B}$ had preferentially negative $\Delta$ values, meaning that removal of these impurities from quartz was more effective than loss of $\mathrm{SiO}_{2}$ in reduction. $\mathrm{Al}$ had positive $\Delta$ value meaning that it was removed less effectively or remained unaltered in the charge. The change in $\mathrm{K}$ concentration was scattered with uncertain trend. $\Delta$ values for $\mathrm{Fe}$ were more negative for lumps in comparison with pellets, meaning that $\mathrm{Fe}$ was more effectively removed - or remained less unaltered in the quartz when pellets instead of lumps were used, in particular when hydrothermal quartz was used.

Impurities in $\mathrm{Si}$ for the " $\mathrm{SiO}_{2}+\mathrm{Si}$ " charge were also analyzed. Results presented in Table VI show that the concentrations of $\mathrm{B}, \mathrm{Fe}, \mathrm{Mn}$, and $\mathrm{Al}$ in silicon increased after reaction. The phenomenon was particularly evident when pellets were used.

As described in the introduction, impurities in quartz are present in the form of trace elements in the quartz lattice and mineral inclusions. The minerals can be partially removed in a beneficiation process when quartz powder is produced; however, they remain in lumpy quartz. Figure 5 illustrates the distribution of Fe, K, and $\mathrm{Al}$ in muscovite mineral, during heating of lumpy quartz. The picture refers to hydrothermal lumpy quartz heated to $1923 \mathrm{~K}$ and $2123 \mathrm{~K}\left(1650^{\circ} \mathrm{C}\right.$ and $\left.1850^{\circ} \mathrm{C}\right)$. As shown in Figure 5, Fe, $\mathrm{K}$, and $\mathrm{Al}$ were partially dissolved into the $\mathrm{SiO}_{2}$-matrix. $\mathrm{K}$ was distributed uniformly in the mineral; while distribution of $\mathrm{Al}$ was not uniform. The concentration of $\mathrm{Fe}$ in the muscovite was too low (4 at. pet Fe compared to 7 at. pct $\mathrm{K}$ and 15 at. pet Al) to describe its behavior. Two distinct liquids were formed: Al-rich melt at the core of the mineral, and a $\mathrm{SiO}_{2}$-rich melt at the mineral boundaries. $\mathrm{Al}$ and $\mathrm{K}$ diffused into the quartz structure at both the temperatures studied.

\section{DISCUSSION}

It was, by microscopic analysis, shown that trace impurities interact with reducing gases: elements in minerals dissolve into the quartz matrix; trace elements in the matrix diffuse toward the neighboring reacting phases or to the quartz surface, where in the presence of a reducing atmosphere, they can leave the quartz in the form of gaseous compounds. Impurities are reduced during quartz reduction and the concentrations of $\mathrm{Mn}$, $\mathrm{Zn}, \mathrm{Al}, \mathrm{Pb}$, and $\mathrm{B}$ diminish after quartz reduction.

\section{A. Quartz Microstructure During Heating}

XRD analyses show that the quartzes, regardless of the initial charge mix, are largely transformed to cristobalite at $1923 \mathrm{~K}\left(1650^{\circ} \mathrm{C}\right)$. The efficiency in cristobalite transformation may be due to the presence of argon in the atmosphere ${ }^{[32]}$ or to the slow heating profile. ${ }^{[33]}$ In particular, looking at the microstructure of reacted lumps of quartz at $1923 \mathrm{~K}\left(1650^{\circ} \mathrm{C}\right)$, amorphous areas can be found (Table IV; Figure 1). The transformation process of quartz into cristobalite takes place right up to $1923 \mathrm{~K}\left(1650^{\circ} \mathrm{C}\right) .{ }^{[20]}$ The amorphous phase which was found in the quartz lumps heated to $1650^{\circ} \mathrm{C}$ $(1923 \mathrm{~K})$ is therefore not melted quartz, but rather the transitional intermediate phase which forms during the "reconstructive transformation" of $\beta$-quartz to $\beta$-cristobalite. ${ }^{[20,34,35]}$ Also, quartz in pellets was completely transformed to cristobalite at $1650^{\circ} \mathrm{C}(1923 \mathrm{~K})$. Quartz microm particles in pellets were mechanically activated by crushing and milling. During mechanical treatment of quartz, (such as milling), Si-O bonds are broken and form a highly disordered silica layers (thickness from 20 to $500 \mathrm{~nm}$ ) on the surface of the quartz fragments. ${ }^{[36-39]}$ 

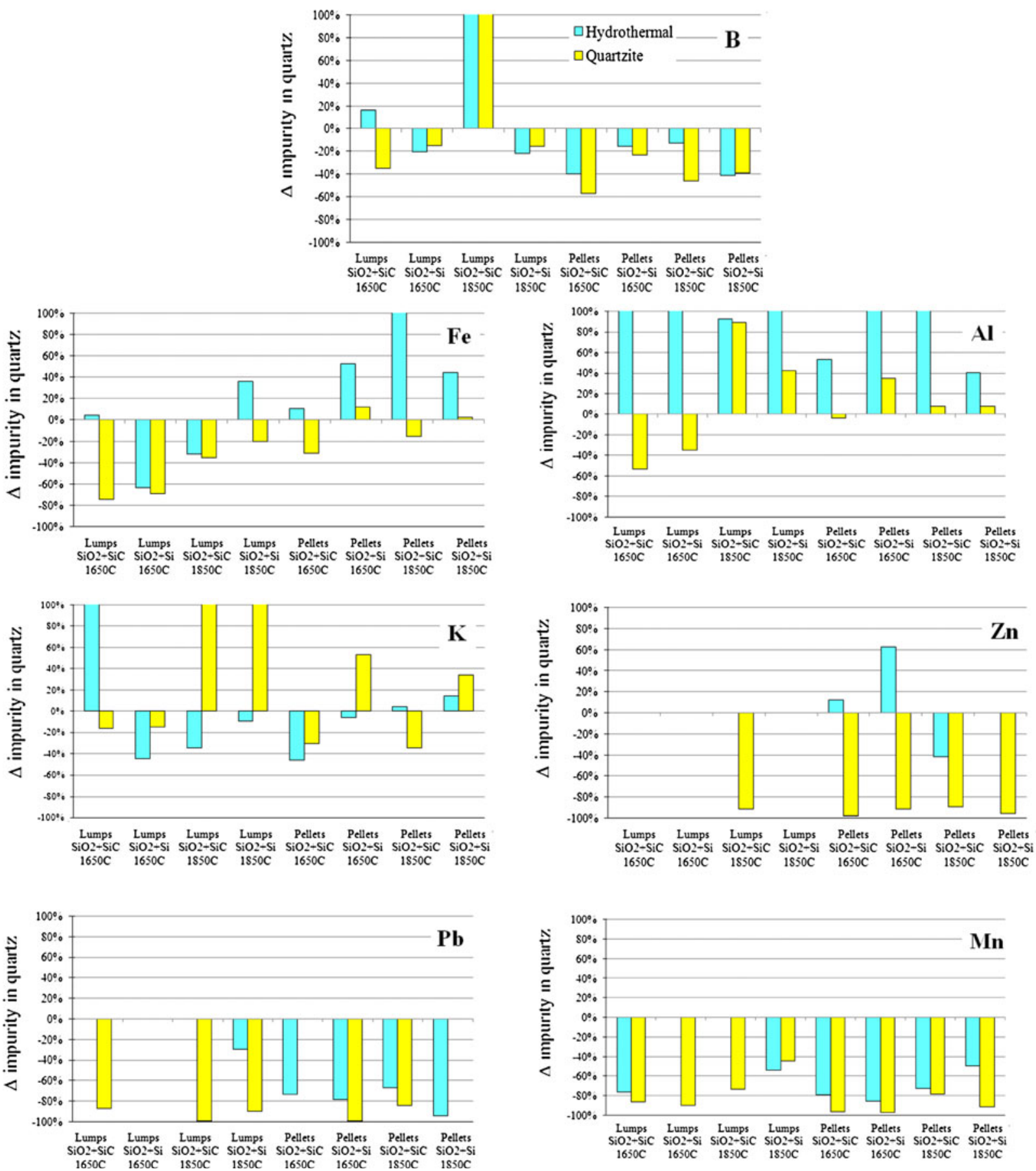

Fig. 4-Impurity variation after quartz reduction compared with the original quartz composition. Values not shown correspond to values below the detection limits or to high concentration in the blanks used as reference.

The high energy content in the activated surface area could also lead to the sintering of the quartz particles. Steinike and Balek ${ }^{[36,38]}$ observed that the direct transformation of mechanically activated quartz transforms directly into cristobalite at lower temperature [around $\left.1473 \mathrm{~K}\left(1200^{\circ} \mathrm{C}\right)\right]$. Cristobalite with density $2.3 \mathrm{~g} / \mathrm{cm}^{3}$ has a more open structure than $\beta$-quartz (density $2.6 \mathrm{~g} /$ $\left.\mathrm{cm}^{3}\right) .{ }^{[40]}$ The solubility of the impurities in cristobalite is therefore higher than in quartz, which stimulates partial decomposition of mineral phase and dissolution of its constituents into cristobalite. Kawasaki ${ }^{[33]}$ reported that the solubility of $\mathrm{Fe}^{3+}$ in cristobalite increases with increasing temperature. Diffusion of $\mathrm{K}, \mathrm{Al}$, and $\mathrm{Fe}$ into the cristobalite structure is shown in Figure 5.

Muscovite mineral melts at temperatures below the quartz melting point. Melted muscovite is associated with a cavity, which was previously filled by $\mathrm{H}_{2} \mathrm{O}$ formed by dehydration of muscovite, a phenomena referring to a process where hydrous silicates recrystallize to an assemblage with fewer or no volatile components. ${ }^{[9]}$ 
Table V. Comparison of the Impurity Content in Quartzite and Hydrothermal Quartz Presented as a Ratio of Concentration in Quartzite to the Concentration in Hydrothermal Quartz

\begin{tabular}{lllllll}
\hline Quartzite/hydrothermal & \multicolumn{1}{c}{$\mathrm{B}$} & $\mathrm{K}$ & $\mathrm{Fe}$ & $\mathrm{Al}$ & $\mathrm{Mn}$ & $\mathrm{Pb}$ \\
\hline Lump initial charge & 1.8 & 2.6 & 10.0 & 10.2 & 8.5 & 10.5 \\
Average reacted lumpy charge & $1.6 \pm 0.5$ & $2.6 \pm 2.1$ & $6.6 \pm 3.2$ & $4.4 \pm 4.0$ & $7.7 \pm 3.8$ & 1.3 \\
Pellets initial charge & 1.5 & 1.4 & 3.1 & 4.7 & 3.3 \\
Average reacted pellet charge & $1.1 \pm 0.4$ & $1.2 \pm 0.9$ & $1.9 \pm 0.5$ & $2.0 \pm 1.4$ & $1.0 \pm 0.8$ & $2.8 \pm 3.2$ \\
\hline
\end{tabular}

Table VI. Chemical Analyses of Reacted Silicon After Heating "SiO $+\mathrm{Si}_{2}$ " Mixtures Compared to the Initial Composition $(\mathbf{E g}-\mathrm{Si}=$ Electronic Grade Silicon)

\begin{tabular}{|c|c|c|c|c|c|c|}
\hline & $\begin{array}{c}\text { B } \\
(p c t)\end{array}$ & $\begin{array}{c}\mathrm{Pb} \\
\text { (pct) }\end{array}$ & $\begin{array}{c}\mathrm{Al} \\
\text { (pct) }\end{array}$ & $\begin{array}{c}\mathrm{Mn} \\
\text { (pct) }\end{array}$ & $\begin{array}{c}\mathrm{Fe} \\
\text { (pct) }\end{array}$ & $\begin{array}{c}\mathrm{Zn} \\
\text { (pct) }\end{array}$ \\
\hline Eg-Si in the charge material & 100 & 100 & 100 & 100 & 100 & 100 \\
\hline Eg-Si after heating to $2123 \mathrm{~K}\left(1850^{\circ} \mathrm{C}\right)$ with lumps of hydrothermal quartz & 79 & 1 & 146 & 2476 & 759 & 6 \\
\hline Eg-Si after heating to $2123 \mathrm{~K}\left(1850^{\circ} \mathrm{C}\right)$ with pellets made of quartzite & 175 & 1 & 168 & 25115 & 2560 & 9 \\
\hline Eg-Si after heating to $2123 \mathrm{~K}\left(1650^{\circ} \mathrm{C}\right)$ with pellets of hydrothermal quartz & 436 & 236 & 1048 & 7174 & 2075 & 100 \\
\hline $\mathrm{Eg}$-Si after heating to $2123 \mathrm{~K}\left(1650^{\circ} \mathrm{C}\right)$ with pellets of quartzite & 173 & 1 & 255 & 5736 & 1754 & 0 \\
\hline
\end{tabular}
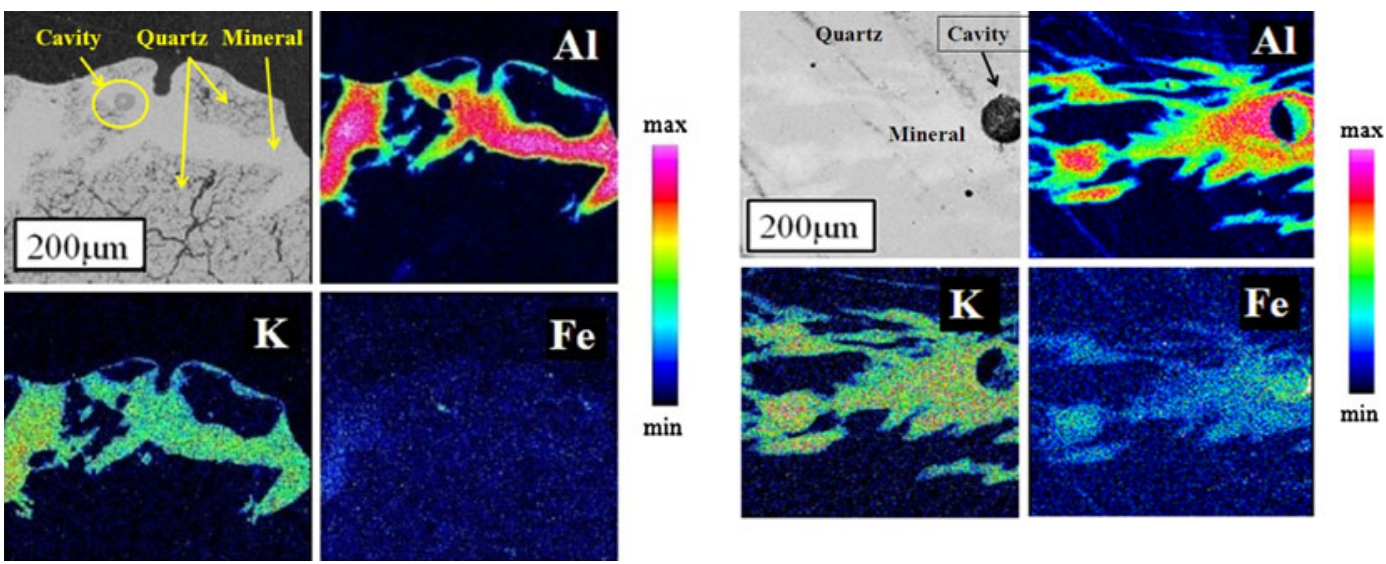

Fig. 5-EPMA mapping of muscovite in hydrothermal quartz heated to $1923 \mathrm{~K}\left(1650^{\circ} \mathrm{C}\right)$ (left) and to $2123 \mathrm{~K}\left(1850^{\circ} \mathrm{C}\right)$ (right). Muscovite melts in two immiscible liquids at temperature above $1923 \mathrm{~K}\left(1650^{\circ} \mathrm{C}\right)$.

The dehydration reaction of mica minerals taking place at calcinations temperatures lower than the melting point of silica was also reported by Zhu. ${ }^{[41]}$ In the muscovite object of this study, $\mathrm{Fe}^{3+}$ partly substitutes for $\mathrm{Al}$ according to the phengite substitution $(\mathrm{Fe}$ is linked to $2 \mathrm{OH}$ and $1 \mathrm{O}$ ). Fe is found concentrated at the cavity showing to have a strong affinity with the $\mathrm{OH}$ group. The diffusion properties of $\mathrm{Fe}$ with $\mathrm{OH}$ is reported by Fein. ${ }^{[42]}$

Two distinct liquids were found in the melted mineral: an Al-rich melt at the core of the mineral, and a $\mathrm{SiO}_{2}-$ rich melt at the mineral boundaries confirming the findings of Hammouda. ${ }^{[8]}$ Figure 5 shows that $\mathrm{Al}$ features a typical diffusion gradient in the silicate mineral, while $\mathrm{K}$ has a constant profile. This gives reason to assume that $\mathrm{Al}$ has a slower diffusion rate than $\mathrm{K}$ when present in a silicate slag matrix, although it has a smaller effective ionic radii than $\mathrm{K}\left(\mathrm{Al}^{3+}\right.$ has an average effective ionic radius of $0.5 \AA$ in comparison to $1.5 \AA$ for $\mathrm{K}^{+[26]}$ ). $\mathrm{K}$, is well known to be a fast diffuser in crystalline quartz because of its interstitial position. ${ }^{[12,14,25]}$

\section{B. Refining of Quartz During Heating Quartz in Reducing Atmosphere}

Reduction of oxides of trace elements depends on the oxides stability and volatility of reduction products. Knowledge of the stability of the oxides with respect to silica and of the boiling temperatures of the reduced volatile compounds is necessary to understand these trends. Oxides more stable than $\mathrm{SiO}_{2}$ (such as $\mathrm{Al}$ ) remained as oxides, while oxides less stable (such as $\mathrm{B}$, $\mathrm{Pb}$, and $\mathrm{Mn}$ ) were reduced during reduction of quartz. $\mathrm{Al}$ is a very stable oxide; as a consequence, it remained primarily in the silica; moreover, as a result of reduction of silica, concentration of aluminum in quartz after reaction increased (Figure 3 ). In addition $\mathrm{Al}^{3+}$ is a slow diffuser in quartz. ${ }^{[16]}$ In contrast to the case of $\mathrm{Al}$, the elements $\mathrm{Pb}, \mathrm{Mn}$, and $\mathrm{B}$ were efficiently removed from 
quartz in the gaseous phase (Figure 4), showing that they were fast diffusers in quartz and easily reduced to gaseous compounds and/or into silicon. Thermodynamically, $\mathrm{B}, \mathrm{Pb}$, and $\mathrm{Mn}$ are less stable as oxides than silica. The extent of removal of boron was lower in comparison with $\mathrm{Mn}$ and $\mathrm{Pb}$. $\mathrm{B}$ has an exception for the experimental condition "lumps $\mathrm{SiO}_{2}+\mathrm{SiC} 2123 \mathrm{~K}$ $\left(1850^{\circ} \mathrm{C}\right)$ " where B is not efficiently removed from $\mathrm{SiO}_{2}$. The experiment lasted 20 minutes only, which was perhaps not sufficient to allow B to diffuse from the bulk lump toward the silica surface boron reduction and removal.

Reduction of impurities in cristobalite took place on the particles surface, which created concentration gradient and diffusion of impurity element from the particle bulk to the surface.

\section{Cracks in Solid Quartz Are Permeated by Reducing Atmosphere}

The diffusion coefficient and diffusion distance of the impurities from the quartz bulk to the surface affects the availability of the impurities at the surface, and therefore, the efficiency of impurity removal reduction. The diffusion distance was relatively short in the micron size pellets. Pellets contained $10-\mu \mathrm{m}$ quartz particles compared to lumps of $5 \mathrm{~mm}$ size (in the real industrial process, $5-15-\mathrm{cm}$ lumps of $5-15-\mathrm{cm}$ size are used). At $1923 \mathrm{~K}\left(1650^{\circ} \mathrm{C}\right)$, cristobalite particles in pellet of $\mathrm{SiO}_{2}+\mathrm{SiC}$ sintered forming clusters of $50-\mu \mathrm{m}$ size, while lumpy quartz developed a thick network of cracks with an average distance between two cracks comparable to $50 \mu \mathrm{m}$. Crack were created by thermal expansion of quartz during heating and its transformation to cristobalite (cristobalite has a density of $2.318 \mathrm{~g} / \mathrm{cm}^{3}$ while quartz has a density of $\left.2.646 \mathrm{~g} / \mathrm{cm}^{3[40]}\right)$. Cracks were also generated by the decrepitation of fluid inclusions which are typical in hydrothermal quartz. ${ }^{[43]}$ Clusters of sintered quartz particles were separated by open spaces greater than $25 \mu \mathrm{m}$, while the fractures in lumps were of the order of several micrometers. Generation of cracks was essential to reaction with gaseous $\mathrm{SiO}$ and $\mathrm{CO}$ and removal of impurities in the reduction process.

It is an open question if the reducing gases can invade the cracks in crystalline quartz.

From a theoretical point of view, if the cracks are wider than the mean free path $\lambda$, then they are invaded by reducing gases through molecular or Ficksian diffusion. The parameter $\lambda$ is the average distance a gaseous molecule travels between collisions. The parameter was calculated according to ${ }^{[44]}$ for $\mathrm{CO}_{2}$ (input data on $\mathrm{SiO}(\mathrm{g})$ and $\mathrm{CO}(\mathrm{g})$ are not available in the literature) under the temperature and pressure conditions described in this article. $\lambda$ is estimated as $\sim 1 \mu \mathrm{m},{ }^{[44]}$ meaning that if the cracks are wider than $\sim 1 \mu \mathrm{m}$, then they are invaded by reducing gases through molecular or Ficksian diffusion, and if, in the least probable case, cracks are smaller than $1 \mu \mathrm{m}$, then the molecules will collide with the crack wall according to Knudsen diffusion theory.

Experimental results confirm this theory. Given similar diffusion distances from quartz bulk to quartz surface in pellets and lumps for the experimental condition " $\mathrm{SiO}_{2}+\mathrm{SiC} 2123 \mathrm{~K}\left(1650^{\circ} \mathrm{C}\right)$," if the reducing gases can invade the microcracks in lumps, then no significant difference between pellets and lumps should be noted after reduction. Figure 4 does not show any particular difference in impurity variation for the experimental condition $\mathrm{SiO}_{2}+\mathrm{SiC} 2123 \mathrm{~K}\left(1650^{\circ} \mathrm{C}\right)$ when quartz lumps instead of pellets are used confirming that $\mathrm{CO}(\mathrm{g})$ and $\mathrm{SiO}(\mathrm{g})$ may permeate the cracks and interact with the impurities available at the surface.

The ability of $\mathrm{CO}(\mathrm{g})$ to invade $\mu \mathrm{m}$ wide cracks, was also demonstrated in previous publications by reacting two quartzes with different initial cracks amount, at high temperature in reducing atmosphere; the quartz having the higher amount of cracks was characterized by higher weight losses. ${ }^{[27]}$

\section{CONCLUSIONS}

This article, which is the first of a series of two, investigated the behavior of the impurities in quartz when quartz reacted with $\mathrm{SiC}$ and $\mathrm{Si}$ in reducing atmosphere.

The main findings of this study can be summarized as follows:

1. $\mathrm{B}, \mathrm{Mn}, \mathrm{Zn}$, and $\mathrm{Pb}$ were removed from quartz during heating in reducing atmosphere at temperatures above $1923 \mathrm{~K}\left(1650^{\circ} \mathrm{C}\right)$.

2. Muscovite in the quartz's mineral phase melted and formed two immiscible liquid phases: an Al-rich melt at the core of the mineral, and $\mathrm{SiO}_{2}$-rich melt at the mineral boundaries.

3. During the heating of quartz in the presence of silicon, $\mathrm{Mn}, \mathrm{Fe}, \mathrm{Al}, \mathrm{Zn}$, and $\mathrm{B}$ diffused from quartz into the silicon; this was particularly evident when pellets were used.

4. Pellets made of only quartz sintered at temperatures below $1923 \mathrm{~K}\left(1650^{\circ} \mathrm{C}\right)$.

5. During the heating of quartz lumps, a thick network of cracks with an average distance between cracks close to $50 \mu \mathrm{m}$ and of the order of micrometer scale formed. Reducing gases can invade these cracks in quartz.

6. Differences in concentrations of impurities in quartzite and hydrothermal quartz decreased upon silica reduction; however, contamination of quartzite remained higher than that of hydrothermal quartz.

\section{ACKNOWLEDGMENTS}

The authors appreciate the inspiring discussions with Kristian Drivenes and Jeffery Kline; this study was possible thanks to the excellent technical help of John Sharp, Xing Xing, and Xiaohan Wan. Thanks are due also to Morten Raaneess and Syverin Lierhagen for their analyses. This study was partially funded by ELKEM's research fund. 


\section{REFERENCES}

1. Panel Discussion: Crystal Clear in the 6th Framework of Program of $E U$. Amsterdam, 2008.

2. H. Yao, H. Minato, I.S.N. Mkilaha, and I. Naruse: J. Jpn. I. Met., 2001, pp. 256-62.

3. Q. Wang, J. Qiu, Y. Liu, and C. Zheng: Fuel Process. Technol., 2004, vol. 85, pp. 1431-41.

4. M. Garcia and E.H. Myrhaug: Revisjon av materialbalanse for sporelementer $i$ Si-ovn basert på målekampanje på Elkem Thamshavn April 2007. Elkem Silicon, Oslo, 2007.

5. E.H. Myrhaug and H. Tveit: Electric Furnace Conference Proceedings, vol. 58. AIST, Warrendale, PA, 2000, pp. 591-04.

6. R. Kvande, L. Nygaard, S. Stute, and P.C.P. Bronsveld: 25th European Photovoltaic Solar Energy Conference and Exhibition/ Conference on Photovoltaic Energy Conversion, Valencia, Spain, 2010.

7. E. Dal Martello, S. Bernardis, G. Tranell, R. Larsen, and M. DiSabatino: Powder Technol., 2012, vol. 224, pp. 209-16.

8. T. Hammouda and M. Pichavant: Eur. J. Min., 1999, vol. 11, pp. 637-53.

9. H. Deer and J. Zussman: An Introduction to The Rock-Forming Minerals. Longman Scientific and Technical, New York, 1992.

10. R.B. Larsen, I. Henderson, P.M. Ihlen, F. Jacamon: Contrib. Min. Petrol, 2004, vol. 147, pp. 615-28.

11. I. Samson, A. Anderson, and D. Marshall: Fluid Inclusions: Analysis and Interpretation, vol. 32. Mineralogical Association of Canada, Vancouver, 2003.

12. B. Flem, R.B. Larsen, A. Grimstvedt, and J. Mansfeld: Chem. Geol., 2002, vol. 182, pp. 237-47.

13. G.H. Frischat: Ber Deut Keram Ges, 1970, vol. 47, pp. 364-68.

14. J. Verhoogen: Am Min., 1952, vol. 37, pp. 637-55.

15. G.H. Frischat: J. Am. Ceram. Soc., 1970, vol. 53, pp. 357-60.

16. R. Pankrath and O.W. Florke: Eur. J. Min., 1994, vol. 6, pp. 435-57.

17. S.C. Penniston-Dorland: Am Min., 2001, vol. 86 (5-6), pp. 652-66

18. H.D. Stock and G. Lehmann: J. Phys. Chem. Solids, 1976, vol. 38, pp. $243-46$.

19. D.J. Cherniak, E.B. Watson, and D.A. Wark: Chem. Geol., 2007, vol. 236 , pp. $65-74$.

20. A.C.D. Chaklader and A.L. Roberts: J. Am. Cer. Soc., 1961, vol. 44 (1), pp. 35-41.

21. V. Presser and K.G. Nickel: Crit. Rev. Solid State Mater. Sci., 2008, vol. 33, pp. 1-99.

22. A. Amington and J. Balascio: 38th Annual Symposium on Frequency Control, 1984, pp. 3-7.
23. A. Muller, W. B.J, and M. Smith: Mineral. Mag., 2005, vol. 69 (4), pp. $381-01$.

24. R.B. Larsen, F. Jacamon, and A. Kronz: Mineral. Mag., 2009, vol. 73 (4), pp. 691-07.

25. R.B. Larsen, I. Henderson, and P.M. Ihlen: Contrib. Min. Petrol, 2004, vol. 147, pp. 615-28

26. E.J.W. Whittaker and R. Muntus: Geochim Cosmochim Ac, 1970, vol. 34, pp. 945-56.

27. E. Dal Martello, G. Tranell, O. Ostrovski, G. Zhang, O. Raaness, R. Larsen, and P. Koshy: Metall. Mater. Trans. B, 2011, vol. 42B (5), pp. 939-50.

28. E. Dal Martello, G. Tranell, S. Gaal, and L. Arnberg: ISIJ Int., 2011, vol. 51 (9), pp. 1492-96.

29. L. Stoch, M. Laczka, and I. Waclawska: Mineralogia Polonica, 1985, vol. 16 (2), pp. 43-54.

30. Astimex: http://astimex.com/com/catalog/min.html. 26th June 2011.

31. Australia Co.S.: Coal and Coke-Analysis and testing Part4: CokeProximate analysis. 2006, Standards Australia GPO Box 476, Sydney, NSW, Australia, 2001.

32. V. Andersen: Investigation of Thermal Properties of Quartz for the Silicon Industry Under Reducing Atmosphere, Department of materials science and engineering. NTNU, Trondheim, 2009.

33. T. Kawasaki and H. Ishizuka: J. Miner. Petrol. Sci., 2008, vol. 103, pp. 255-65.

34. G. Scherer, P.J. Vergano, and D.R. Uhlmann: Phys. Chem. Glasses, 1970, vol. 11 (3), pp. 53-58.

35. S. Mitra: Trans. J. Br. Ceram. Soc., 1977, vol. 76 (4), pp. 71-74.

36. V. Balek, J. Fusek, J. Křiž, and M. Murat: Thermoc. Acta, 1995, vol. 262, pp. 209-14.

37. J.C. Benezet and A. Benhassaine: Powder Technol., 1999, vol. 105 (1), pp. 167-71.

38. U. Steinike and K. Tkáčová: J. Mater. Synth. Process., 2000, vol. 8, pp. 197-03.

39. C. Damn and W. Peukert: Langmuir, 2009, vol. 25, pp. 2264-70.

40. H.M. Ford, S.M. Auerbach, and P.A. Monson: J. Chem. Phys., 2004, vol. 121 (17), pp. 8415-22.

41. B. Zhu, Y. Sun, and C. Xie: J. China Coal Soc., 2008, pp. 1049-52.

42. J.B. Fein, J.J. Hemley, W.M. D'Angelo, A. Komninou, and D.A. Sverjensky: Geochim Cosmochim Ac., 1992, vol. 56, pp. 3179-90.

43. M. Gemeinert, M. Gaber, I. Hager, M. Willfahrt, and D. Bortschuloun: Neues Jahrbuch Miner. Abh., 1992, vol. 165 (1), pp. 19-27.

44. P. Atkins and J. de Paula: Atkins' Physical Chemistry, $7^{\text {th }}$ ed. Oxford University Press Inc, New York, 2002. 